\title{
Long-term Database of Sandy Grassland of Fulophaza
}

\author{
Tamás Rédei, György Kröel-Dulay \& Anikó Csecserits
}

\begin{abstract}
The aim of database is to follow the changes of open perennial sandy grasslands (Festucetum vaginatae) in Kiskunság/Hungary, which are almost without any direct human management. Our goal is to predict the effects of the climatic change on the dominance and the composition of the Pannonian sand forest steppe vegetation. The region is heavily threatened by climatic change as regional scale models predict the intensification of the summer drought. This causes a significant dieback of the dominant perennial grasses. The dieback is followed by regeneration periods in the less arid years, but the proportion of the dominant species, and the species composition is continuously changing. The study started in 2000 and was repeated every two years to 2010 , and we aim at continuing at least in the next decade.
\end{abstract}

Keywords: calcareous sandy grassland; Hungary; Kiskunság.

\begin{tabular}{|c|c|}
\hline GIVD Database ID: EU-HU-002 & Last update: $2011-07-06$ \\
\hline \multicolumn{2}{|l|}{ Long-term Database of Sandy Grassland of Fulophaza } \\
\hline \multicolumn{2}{|c|}{$\begin{array}{l}\text { Scope: The database was built to follow the changes of a sandy grassland in Kiskunság/Hungary, which is almost without any direct human } \\
\text { management. The study started in } 2000 \text { and sampling was done in every } 2 \text { years. }\end{array}$} \\
\hline Status: completed and continuing $\quad$ Period: $2000-2010$ & \\
\hline \multicolumn{2}{|l|}{ Database manager(s): Tamás Rédei (redy@botanika.hu) } \\
\hline \multicolumn{2}{|l|}{ Owner: Institute for Ecology and Botany } \\
\hline \multicolumn{2}{|l|}{ Web address: $[N A]$} \\
\hline Availability: according to a specific agreement & Online search: no \\
\hline Database format(s): Excel & rcel \\
\hline \multicolumn{2}{|l|}{ Publication: no } \\
\hline Plot type(s): time series & $16 \mathrm{~m}^{2}$ \\
\hline Estimate of existing plots: 3,000 & Completeness: $7 \%$ \\
\hline Total plot observations: 1,200 & Valid taxa: 93 \\
\hline \multicolumn{2}{|l|}{ Countries: HU: $100.0 \%$} \\
\hline \multicolumn{2}{|l|}{ Forest: $[N A]$ - Non-forest: [NA] } \\
\hline \multicolumn{2}{|l|}{ Guilds: all vascular plants: $100 \%$} \\
\hline \multicolumn{2}{|c|}{ Environmental data: altitude: $100 \%$; slope aspect: $100 \%$; slope inclination: $100 \%$; microrelief: $100 \%$; soil depth: $100 \%$} \\
\hline \multicolumn{2}{|l|}{ Performance measure(s): cover: $100 \%$} \\
\hline \multicolumn{2}{|l|}{ Geographic localisation: GPS coordinates (precision 25 m or less): 100\% } \\
\hline Sampling periods: $2000-2009: 80.0 \% ; 2010-2019: 20.0 \%$ & \\
\hline Information as of 2012-07-12; further details and future updates available & m http://www.givd.info/ID/EU-HU-002 \\
\hline
\end{tabular}

Tamás Rédei (redy@botanika.hu), György Kröel-Dulay (kroel-dulay.gyorgy@ okologia.mta.hu), Anikó Csecserits* (csecserits.aniko@okologia.mta.hu),

Plant Ecology, Institute for Ecology and Botany, HAS, Alkotmany 2-4., 2163 Vacratot, HUNGARY

*Corresponding author 